\title{
Past, present, and future of the concept of information
}

\author{
Rafael Capurro
}

Steinbeis-Transfer-Institut Information Ethics (STI-IE) Redtenbacherstrasse 9, 76133 Karlsruhe (Germany), E-mail: rafael@capurro.de; Web: http://www.capurro.de/

\begin{abstract}
This text provides an overview of the complex history of the concept of information in the Greek-Latin as well as in the Medieval and Modern traditions. It connects the Latin etymology of the term informatio with the Greek concepts of eidos/idea and morphé and shows how the objective meaning of information ('giving form to something') becomes obsolete in modernity where only the communicational meaning ('telling something (new) to someone') remains. Information theories in the 20th Century are related to the development of technical systems of message transmission. They give rise to a renaissance of the objective notion of information but under a different framework as the one of the classic pre-modern philosophy. Establishing a connection between the concepts of information and message several options are presented leading to a concept of information based on a theory of messages.
\end{abstract}

Keywords: information, concept, history, message, informatio.

Acknowledgement: The following text is partly based on the common article by Rafael Capurro and Birger Hjørland (Capurro \& Hjorland, 2003). All changes and additions are by Rafael Capurro. This text was originally written in Spanish. The author thanks Fernando Elichirigoity (University of Illinois at Urbana-Champaign) for polishing this translation. He also thanks José María Díaz Nafría (Universidad Alfonso X) and Mercedes Osorio for their careful proofreading of the manuscript.

\section{$\mathrm{T}$} o explore the history of a concept can be boring and useless as far as such history gives a mere account of semantic changes petrified in encyclopaedias and related to obsolete scientific theories or philosophical speculations of purely historical interest. This is evident where such analysis refers just to notions, i.e., to words and their signifiers. In this case the analysis does not deal with the apparent adequacy of a concept with a phenomenon but with the history of semantic changes in different languages. These changes are even more unclear and accidental as in the case of scientific or philosophical concepts. We find them also petrified in etymological dictionaries that only a naïve mind might consider as a source of the supposed true meaning of a term, which is precisely the etymological meaning of the term etymology, which comes from Greek étymon which means the true sense as opposite to a lie. Homer tells, or better: sings, how Ulysses deceives Penelope: "Many a plausible tale (étymoisin homoia) did Ulysses further tell her" (Od. 19, 203), without revealing her his true identity and without telling her, of course, about his erotic adventures with Circe, Calypso, the sirens and Nausicaa, to mention just a few highlights from his travel back home that took him some ten years.

What positive and productive sense might arise from the analysis of the past, present, and future of the concept of information? The answer to this question depends upon what we understand by language. The relation between human, world and language has been one of the main themes of philosophy in the $20^{\text {th }}$ Century with regard to what has been called the linguistic turn that took place in analytic philosophy as well as in some philosophical schools of continental philosophy such as phenomenology and hermeneutics influenced particularly by 
linguistics and semiotics. Under this perspective language is not a neutral and transparent medium but an unavoidable condition that pervades our knowledge of reality as well as our action upon it. This means, following the Kantian tradition, that reality is being articulated in language and vice versa, the analysis of language shows, although under certain implicit conditions, who we are and in which world we live. This was particularly emphasized by Wittgenstein with his conception of "meaning as use" and the relation of such use(s) to "forms of life" and "language games." Without overemphasizing Wittgenstein's linguistic pragmatism, I would like to stress the insight that our knowledge about the world as well as about our actions upon it cannot avoid language, although it is possible to take a critical distance from the contingent meanings of notions, i.e., of the different uses of words in everyday language, and concepts, i.e., the definition of a notion within a theory, allowing us not only to create new "forms of life" but also new scientific theories.

From this perspective the analysis of the history of a concept, including its signifiers, becomes a task similar to the one of a geologist who tries to reconstruct natural processes, by exploring now world views based on traces that often appear as almost insignificant, laid down on different material and/or linguistic carriers interrelated through underground currents in different epochs. Geology becomes genealogy (Capurro, 1996) pp. 259-270). A genealogical analysis is particularly interesting if such concepts are being used to characterize a society or even a whole epoch. It is even crucial when we want to give plausible reasons why they have acquired such a relevance and how we can change them and their underlying "forms of life" as well.

We live, it has been said many times, in an information society or even in an information age as opposed to the industrial and the agrarian ones. Of course, such epoch

See Ludwig Wittgenstein: Philosophische Untersuchungen. In ibid. Werkausgabe, Band 1. Frankfurt am Main: Suhrkamp 1984, § 43: „Die Bedeutung eines Wortes ist sein Gebrauch in der Sprache“ („The meaning of a word is its use in language"). See also $\S 23,138$, 156. divisions are somehow arbitrary particularly if seen within a linear evolution while in fact every human society is based on informational processes although not of the same kind as the present digital information media. The predominance of a distinctive factor allows us, for good or for bad, to use adjectives in order to qualify an epoch, while other aspects, maybe no less relevant, remain hidden. Every concept is embedded in a historical network of relations which include metaphoric and metonymic changes in natural languages as well as in artificial ones including scientific theories and philosophic speculations. Such changes can be observed in all their complexity particularly in classical literary works. In the field of philosophy these changes are crucial at least as far as philosophy is understood as a methodological reflection on the conceptual basis of the world and the human being. The Historical Dictionary of Philosophy is an example of such a genealogical conceptual analysis that took some thirty years to get done and whose result is, I believe, neither boring nor useless. ${ }^{2}$

If the human world is a world of things that we either discover or make and share within and from language - including also what is beyond language, to which concepts such as the Kantian "things in themselves" or Lacan's "the real" point to - and if we understand the expression 'the world of language' in both senses of the genitive (subjectivus and objectivus), then we can undertake the task of exploring the past, present, and future of the concept of information which is maybe one of the most popular and controversial of our age not only in everyday life but also in scientific theories, particularly since the second half of the 20th Century. ${ }^{3}$

My interest in this matter arose some thirty years ago from the paper of the German physicist and philosopher Carl Friedrich von Weizsäcker (1912-2007) "Language and

\footnotetext{
${ }^{2}$ Joachim Ritter et al. (Ed.): Historisches Wörterbuch der Philosophie. Darmstadt: Wissenschaftliche Buchgesellschaft (1971-2007), 13 Vols. See particularly H. Schnelle: Information, pp. 116-117.

${ }^{3}$ For a detailed analysis of the etymology of the concept of information see my: Information. Ein Beitrag zur etymologischen und ideengeschichtlichen Begründung des Informationsbegriffs. Munich: Saur 1978. [Online version] <http://www.capurro.de/info.html>.
} 
Information," presented for the first time in 1959 at the Academy of Fine Arts in Munich (Weizsäcker, 1974). Weizsäcker writes:

"Today we are accustomed to think about information as something different from matter and consciousness. But what we have discovered is in fact an old truth in a new place. It is Plato's eidos or the Aristotelian form, appearing in such a way that also a human being of the $20^{\text {th }}$ Century can guess their meaning." [my translation] (Weizsäcker, 1974)

Weizsäcker points implicitly to the famous dictum by Norbert Wiener (1894-1964):

"Information is information, not matter or energy. No materialism which does not admit this can survive in the present day." (Wiener, 1961, p.132)

Obviously, a critical history of the concept of information is so complex that it cannot be dealt with within the framework of this short article. My objective is to point to some paths for future work, in the context of a society that defines itself as information as well as knowledge society, an addition arising probably from some kind of bad conscience with regard to that concept.

The brevity of this presentation compels me to simplify extremely this history. My paper has a relatively simple message. The concept of information in classical antiquity, particularly in the philosophy of Plato and Arisotle, is closely related, as Weiszäcker suggests, to the concepts of idea/eidos and morphé having an objective as well as a subjective meaning - if it is permitted to use this modern categories - that are retained in the Latin tradition with the concept of informatio. Modernity rejects the objective meaning in everyday language and conceives information as a purely subjective category. Today there is a renaissance of the objective meaning of the concept of information within the context of the natural sciences as well as of a technology that is being called precisely information technology. This has a backward effect on the use of this notion in everyday language today as well as on our selfappraisal.

Of course, to follow the path opened by Weizsäcker means to take a genealogical decision relating the concept of information to its everyday present subjective sense of 'communicating something (new) to someone' and to project this concept some 2.500 years back without asking which terms other than eidos or morphé in the Greek (and Latin) tradition could better match the present subjective use such as, for instance, the complex concept of lógos (word, language) as well as the concept of angelía (message). We are thus addressing the problem of translation that can never find an adequate solution just because every concept in different languages and historical situations has a context, an echo, and a different semantic network including the scientific and philosophic theories in which concepts are embedded. In other words, our history is immersed from scratch into what $20^{\text {th }}$ Century philosophy has called the "hermeneutic circle" (Hans-Georg Gadamer) or the "indeterminacy of translation" (W.V.W. Quine).

The task before us is to explore past and present semantic changes of a concept, its uses and relations, without oversimplifications and without forgetting points of reference that could allow us not only to know conjecturally the past from our present perspective but also to take a distance from it by observing us from the past in order to open us to future semantic changes that would be, according to Wittgenstein, "forms of life" as well. From this perspective our task becomes not only academically interesting but also practically and ethically relevant.

\section{The notion and concept(s) of information in the past}

The British philosopher John L. Austin (1911-1960), one of the founding fathers of the philosophy of language, writes:

" $[A]$ word never - well, hardly evershakes off its etymology and its formation. In spite of all changes in the extensions of and additions to its meanings, and indeed rather pervading and governing these, there will still persist the old idea. [...] Going back into the history of a word, very often into Latin, we come back pretty commonly to 
pictures or models of how things happen or are done." (Austin, 1961, pp. 149-150)

The term information has a Latin origin. Informatio has two fundamental meanings, namely the action of giving a form to something material' as well as 'the act of communicating knowledge to another person.' Both meanings, the ontological and the epistemological, are closely related. ${ }^{4}$ The prefix in has in this case the meaning of accentuating an action but it can also mean a negation like in informis (without form). The term informatio is used by classical authors such as Vergil (70-19 B.C.) when he describes in his Aeneid how Vulcan and the Cyclops hammered out (informatum) with their hands lightening bolts for Zeus (Aen. 8, 426). Tertullian (ca. 160-220 A.D.) calls Moses populi informator, that is, people's educator or molder, a pedagogical and political meaning that remains for many centuries in some Western languages derived from Latin.

If we follow Weizsäcker's path we can further ask if there is any text in classical or medieval philosophy where the term informatio has the same or a similar technical meaning as well as an explicit relation to the complex Greek philosophical concepts of idéa/eidos and morphé. The answer is yes in case of prominent thinkers such as Cicero (106-43 B.C.), Augustine (354-430 A.D.), and Thomas Aquinas (1225-1274 $\quad$ D.C.), to mention a few of them. Cicero, for instance, translates in De natura deorum the Epicurean concept of prólepsis, i.e., the representation of the images of the gods and things in the human soul as informatio rei (nat. deor. 1, 43). In a rhetorical context Cicero wants to describe vividly or depict (informato) the ideal rhetorician (orat. 7) whose highest performance is to be able to observe "what Plato calls ideas" (orat. 10). In another work Cicero defends his master, the Greek poet Archias, born in Antiochia and accused of having acquired illegally the Roman citizenship, by pointing to the fact that he, Cicero, was educated by Archias in tecniques such as writing whose aim is to educate or 'inform" young people in order to become a true

\footnotetext{
${ }^{4}$ Bibliographic data of classical sources as well as of many other texts to which I refer in this article can be found in my Information,op.cit.
}

human being (quibus aetas puerilis ad humanitatem informari solet) (Arch. 3).

The influence of Greek ontology and epistemology with regard to the technical or conceptual use of informatio is also highly relevant in Augustine as well as in Thomas Aquinas. Augustine calls in De trinitate the process of visual perception "the moulding of sensory perception" (informatio sensus) (trin. $11,2,3$ ) pointing to the Platonic (Theaet. 191d) and Aristotelian epistemological metaphors (De an. 424 a 17) of the impression (imprimitur) of a ring seal into wax, i.e., into memory. The Greek word for a ring seal is daktylios, Latin digitus, where our term digital comes from. This process is related, as I will show later, to the concept of message, as far as the impression of a form or structure in a medium can be understood as the communication of a message. In De civitate dei Augustine calls the process of illumination of the heavenly community informatio civitatis sanctae (civ. 11, 24).

The concept of informatio is a key one in Thomas Aquinas' epistemology and ontology. Aristotle's hylemorphism is translated by Aquinas as the process of 'in-forming' matter (informatio materiae). Such process is interpreted within the background of Christian creational metaphysics that leads Aquinas to clearly distinguish between physical and biological 'in-formation' processes (per modum informationis) - particularly the 'information' of the body by the soul - from the divine creational activity (per modum creationis). ${ }^{5} \quad$ This difference between informatio and creatio is alien to Greek thought. The Platonic demiourge is a "pottery god" (Margel, 1995) whose activity, from Aquinas' perspective, is only per informationen while the Christian god is a transcendent cause who creates things "out of nothing" (ex nihilo). Thomas Aquinas makes thus compatible in an elegant way today's opposition between the creationist vs. the evolutionary approaches. From an epistemological perspective he distinguishes between the "moulding of sensory perception" (informatio sensus) and the "moulding of the intellect" (informatio intellectus). He connects

\footnotetext{
127.
} 
both processes following the Aristotelian doctrine of "turning round towards the senseappearances" (conversio ad phantasmata) (Summa theol. I, 14.2. co/4). Aquinas underlines the role of the active intellect (intellectus agens) in the process of 'recognizing' the forms separated or abstracted from the phenomena. Eventually he uses the term informatio in a pedagogical and ethical context understood as modelling virtues (informatio virtutum) and moral customs (informatio morum) (Summa theol. III, 110.4.co/15).

This broad technical use of informatio is common but not identical to many medieval authors. It is codified in general encyclopaedias as well as in philosophical dictionaries from the $18^{\text {th }}$ Century on, often with the remark that the ontological meaning does not belong any more to everyday language being only a terminus technicus in philosophy. ${ }^{6}$ This remark in a typical dictionary style records briefly something apparently neutral and objective, but it entails in fact no less than a paradigmatic change from the medieval world view based on Greek-roman philosophy, and particularly on Aristotelian thought, into the modern subjective view of information as well as into scientific theories based upon or derived from such a view. The shift from the conception of information as an objective process to a subjective one is common to European languages deriving from Latin such as Spanish, French or Italian as well as to the ones influenced by it, such as English, from the $14^{\text {th }}$ Century on. I take as an example the listing of meanings of the Spanish term información and its derivates recorded in the Dictionary of the Spanish Language called de Autoridades published in Madrid in $1734 .^{7}$ As its heading información states the ontological meaning of information does not belong any more to everyday language being only a technical term, i.e., a

\footnotetext{
${ }^{6}$ See for instance Antoine Furetière: Dictionnaire universel contenant tous les mots françois tant vieux que modernes, \& les termes de toutes les sciences et des arts. The Hague, Rotterdam: La Veuve van Dole 1725 (1st ed. 1690): "Informer, v. act. Servir de forme. II ne se dit en ce sens qu'en phrase philosophique. L'âme informe le corps» as well as my Information, op.cit. pp. 155 ss.

${ }^{7}$ See Annex. See also my Information, op.cit. pp. 140 ss.
}

concept of Scholastic philosophy. What is the reason for such a shift? The answer seems obvious, namely, no more and no less than the slow transformation of the substantial view of the subject into the modern communicational subject enforced by the decline of Scholastic philosophy which was caused by the rise of modern empirical science since the $17^{\text {th }}$ Century. This thesis needs, of course, a deeper and more detailed analysis. ${ }^{8}$ The transition from the Middle Ages to Modernity that can be observed in the loss in everyday language of the objective meaning of information ("giving a (substantial) form to matter") retaining the subjective one ("communicating something (new) to someone") can be clearly detected in the natural philosophy of René Descartes (15961650 ), who calls ideas the "forms of thought," not in the sense that these are "pictured" (depicate) in some part of the brain, but "as far as they inform the spirit itself oriented to this part of the brain." ${ }^{\prime \prime}$ Descartes separates radically, in opposition to Aristotelian and Scholastic philosophy, the sensory processes from the immediate and conscious knowledge of ideas. As André Lalande remarks, this text clearly shows the shift from the Scholastic meaning of "giving form to matter" ("donner une forme à una matière") to the modern use of "giving someone knowledge about something" ("faire connaître quelque chose à

\footnotetext{
${ }^{8}$ John D. Peters: Information: Notes toward a critical history. Journal of Communication Inquiry, 12, 1988, p. 12: "In the feverish demolition of medieval institutions in the seventeenth and eighteenth centuries, the notion that information consisted in the activity or process of endowing some material entity with form remained largely unchanged. But the notion that the universe was ordered by forms fell into disrepute, and the context of this informing shifted from matter to mind. Both changes inaugurated a massive inversion in the meaning of information."

${ }^{9}$ René Descartes: Meditationes de prima philosophia. Secundae Responsiones. In ibid. : Oeuvres, C. Adam \& P. Tannery (Eds.). Paris: Vrin 1996, Vol. VII, pp. 160161: «Ideae nomine intelligo cujuslibet cogitationis formam illam, per cujus immediatam perceptionem ipsius ejusdem cogitationis conscius sum ; adeo ut nihil possim verbis exprimere, intelligendo id quod dico, quin ex hoc ipso certum sit, in me esse ideam ejus quod verbis illis significatur. Atque ita non solas imagines in phantasia depictas ideas voco; imo ipsas nullo modo voco ideas, quatenis sunt in phantasia corporea, hoc est in parte aliqua cerebri depictae, sed tantum quatenus mentem ipsam in illam cerebri partem conversam informant.»
} 
quelqu'un") (Lalande, 1991, p.514). The Cartesian methodological doubt has a purely rational instrument - Kant will later call it a priori - that allows the ability to judge clearly and distinctively the unfaithful empirical data. Descartes' doctrine of ideas is heavily relevant to modern empiricism as well as to rationalism. ${ }^{10}$

The criticism of hylemorphism and of the Aristotelian theory of abstraction are classical themes of philosophers such as Francis Bacon (1561-1625), John Locke (1632-1704), George Berkeley (1685-1753), David Hume (1711-1776) or Thomas Reid (1711-1796), but in many cases this is a seemingly critical appraisal particularly when empiricist theories use the term information(s) as well as impression(s). ${ }^{11}$ The break between Scholasticism and modernity concerns less the concept of information as the question about its range or specific domain which, for modernity, is human knowledge and not something underlying all natural processes. The modern concept of information looses also the epistemological meaning as related to metaphysical or theological questions as well as to most pedagogical and moral applications of medieval informatio. The

10 J.D. Peters, op.cit. p. 13: "The "doctrine of ideas," developed initially by Descartes, was central to early modern philosophy, both rationalist and empiricist. Abandoning the "direct perception" of the scholastics the immediate communion of Intellect and Nature Descartes interposed "ideas" between the two. An "idea" was something present to the mind, an image, copy, or representation, with a problematic relation to real things in the world. For empiricists (like Locke), the stream of ideas was the raw material from which genuine knowledge could be built; for rationalists (like Descartes), it was a veil of illusion, to be pierced by logic and reason."

11 According to J.D. Peters, op.cit. p. 12, Bacon criticizes in the Great Instauration "the logicians of his day for receiving "as conclusive the immediate informations of the sense..." Instead, those "informations" must be subjected, according to Bacon, to a sure plan that will sort the true form the false. Though Bacon's usage may not appear irreconcilable with our own, the inverted pluralization should tip us off that he does not completely share our prejudices (we should say "the information of the senses"). In fact, this locution exemplifies a perfectly hylomorphic notion of the workings of the senses: they are a kind of matter (wax being a favorite empiricist instance) on which objects of the world may leave their shapes or stamps. What is interesting here is that the site of information is being shifted from the world at large to the human mind and senses. This shift requires no break with scholastic notions of mind or nature." meaning of information is reduced to the exchange of knowledge about the world. It is neither related to the formative sensory processes themselves nor to moral enhancement. The key aspect of the modern epistemological concept of information is the human action of communicating (new) knowledge to someone. The Diccionario de Autoridades puts it in the most concise way:

"To inform. Means also to communicate news to someone or in the very fact of telling him something. Lat. Informare. Certiorem facere." ${ }^{12}$ [My translation]

One testimony of this use is taken from Miguel de Cervantes (1547-1616) who describes how Don Quixote, the hero of liberty, asks to be told, i.e., informed why some wrongdoers were put in chains:

"The chain of galley slaves had by this time come up, and Don Quixote in very courteous language asked those who were in custody of it to be good enough to tell him ["informalle $y$ decille"] the reason or reasons for which they were conducting these people in this manner. One of the guards on horseback answered that they were galley slaves belonging to his majesty, that they were going to the galleys, and that was all that was to be said and all he had any business to know.

"Nevertheless," replied Don Quixote, "I should like to know from each of them separately the reason of his misfortune;" to this he added more to the same effect to induce them to tell him what he wanted so civilly that the other mounted guard said to him:

"Though we have here the register and certificate of the sentence of every one of these wretches, this is no time to take them out or read them; come and ask themselves; they can tell if they choose, and they will, for these fellows take a pleasure in doing and talking about rascalities."

With this permission, which Don Quixote would have taken even had they not

${ }^{12}$ See Annex. 
granted it, he approached the chain and asked the first for what offences he was now in such a sorry case.

He made answer that it was for being a lover.

"For that only?" replied Don Quixote; "why, if for being lovers they send people to the galleys I might have been rowing in them long ago."

"The love is not the sort your worship is thinking of," said the galley slave; "mine was that I loved a washerwoman's basket of clean linen so well, and held it so close in my embrace, that if the arm of the law had not forced it from me, I should never have let it go of my own will to this moment." (Cervantes, 1991, Vol. I, chapter 22).

This text clearly shows the modern use of the notion of information within an epistemological and communicational context related to the plausibility of the knowledge transmitted based on oral as well as on written communication, particularly on official documents that, if necessary, might be read publicly. We may at this point suspect that the modern notion and concept of information is not only based etymologically on concepts such as eidos/idéa and morphé or forma but also, as far as it means 'telling something (new) to someone,' on the concept of lógos and related therefore to the birth itself of philosophy. I will come back to this issue.

\section{The notion and concept(s) of information today}

The modern subjective notion of information plays a key role in the so-called information society that emerges after World War II together with a scientific discipline that has its roots in bibliotecology, computer science, and engineering. The application of computation to (scientific) bibliography gives rise to information science, also called documentation or library and information science (LIS) particularly in the Anglo-Saxon world. Within the societal context, information is seen more and more as something basic to the functioning of society together with capital, work and raw material.
The birth certificate of the today's concept of information is without doubt the article by Claude E. Shannon (1916-2001) A Mathematical Theory of Communication (1948) where he refers to the everyday semantic and pragmatic dimensions of the notion of information understood as the meaning of a message. Shannon's theory deals with the question of how to reproduce a message on the basis of its symbolic codification. ${ }^{13}$ According to Shannon what a sender transmits to a receiver is not information but a message. He classifies the communication systems, i.e., the systems of message transmission, in three categories, namely discrete (telegraphy), continuous (radio and TV) and mixed ones. Shannon's definition of information deals strictly with the potential selections of messages or, more precisely, of the signs available in order to codify them. This theory does not deal with communication as transmission of meaning or with information as the meaning of a message. It is a theory of the codification and transmission of messages. Shannon makes a correlation between information, i.e., the number of possible selections needed for the creation of a message, and the improbability for such selection. This concept of information is, as Warren Weaver (1894-1978) remarks "disappointing and bizarre." (Shannon \& Weaver, 1972, p.27) It is disappointing because it has nothing to do with the everyday notion in English or in other European languages for over, say, the last five hundred years. And it is bizarre because it equates two terms that are apparently opposed, namely information and uncertainty. What Shannon aims to quantify is not an information flow but the transmission of messages that can be continuous, discrete or

${ }^{13}$ Claude E. Shannon and Warren Weaver: The mathematical theory of communication. Urbana, IL: University of Illinois Press 1972 (orig. 1949), p. 31: "The fundamental problem of communication is that of reproducing at one point either exactly or approximately a message selected at another point. Frequently the messages have meaning; that is they refer to or are correlated according to some system with certain physical or conceptual entities. These semantic aspects of communication are irrelevant to the engineering problem. The significant aspect is that the actual message is one selected from a set of possible messages." 
mixed. ${ }^{14}$ This transmission is based on a medium or, more precisely, on a messenger and is understood as a formal relation between messages. By disconnecting the concepts of information and message from their ancient and modern epistemological context, Shannon opens new vistas towards an objective or formal use of these concepts, explicitly setting aside the semantic and pragmatic aspects which are specific to psychic and social systems an to the modern use of the notion of information. We are at the eve of Norbert Wiener's (1894-1964) cybernetics and its further transformations that provoked a long and sometimes ideological discussion opposing subjective and objective meanings and seeking for a unified theory of information (Pérez-Montoro, 2007). This debate is a testimony of the complex history of this notion and concept(s) and its interrelation with the notion and concept(s) of message.

An example of this debate is the book edited by Fritz Machlup and Una Mansfield The Study of Information: Interdisciplinary Messages, where Machlup defends the subjective notion of information in its ordinary meaning of messages sent and/or received by the human mind and criticizes the use of this term in a technical context. ${ }^{15} \mathrm{It}$ is interesting to

\footnotetext{
14 Ibid. p. 34-35: "We may roughly classify communication systems into three main categories: discrete, continuous and mixed. By a discrete system we will mean one in which both the message and the signal are a sequence of discrete symbols. A typical case is telegraphy where the message is a sequence of letters and the signal a sequence of dots, dashes and spaces. A continuous system is one in which the message and signals are both treated as continuous functions, e.g., radio or television. A mixed system is one in which both discrete and continuous variables appear, e.g., PCM transmission of speech." PCM (Pulse-code modulation) is the digital representation of an analogical signal.

15 Fritz Machlup: Semantics quirks in studies of information. In: Fritz Machlup and Una Mansfield (Eds.): The Study of Information. Interdisciplinary Messages. New York: Wiley, 1983, p. 660. "[...]to telling something or to the something that is being told. Information is addressed to human minds and is received by human minds. [...] The requirement of truth or correctness should exclude false or incorrect messages; the requirement of value or usefulness should exclude messages not helpful in decisions and actions; the requirement of novelty should exclude repeated or redundant messages; the requirement of surprise should exclude messages that the recipient expected; the requirement of uncertaintyreduction should exclude messages that leave the
}

see how this debate focuses on the concept of information while both, Machlup and Shannon, use the notion of message. It is also important to remember that the technical concept of information arises since the end of the $19^{\text {th }}$ and the beginning of the $20^{\text {th }}$ Century when used by physicists and engineers like Ludwig Boltzmann (1844-1906), John von Neumann (1903-1957), Leo Szilard (18981964), Harry Nyquist (1889-1976) and Ralph V.L. Hartley (1888-1970) who publishes in 1928 an article Transmission of Information where he postulates that since the systems of electronic transmission have nothing to do with human beings but with machines "[...] it is desirable therefore to eliminate the psychological factors involved and to establish a measure of information in terms of purely physical quantities" (Hartley, 1928, p. 536). The philosophical debate concerning the process of naturalization or objectification of the concept of information, i.e., its (re)location beyond the human sphere, has its roots in the natural sciences but also in engineering and in computer science. When Norbert Wiener refers to the concept of information as something different from matter and energy, he is implicitly questioning dialectical materialism. ${ }^{16}$ But in this present objective use of the concept of information there are fundamental changes with regard to its use in the context of classic Greek and Latin philosophy namely

- The meta-historical celestial place (topos noetós) of Platonic ideas is now occupied by worldly evolution.

- The place of nature (physis) is now occupied by quantum mechanics.

- The Platonic notion of participation (méthexis) is being substituted by the one of communication.

recipient's state of uncertainty unchanged or increased; and so forth. No exhaustive enumeration of persuasive or dictatorial restrictions is here intended."

${ }^{16}$ For an example of the dialectical materialist concept of information see A.D. Ursul: Information: Eine philosophische Studie. Berlin: Dietz 1970. Wiener's idea was further developped by Gotthard Günther: Das Bewußtsein der Maschinen: Eine Metaphysik der Kybernetik. Krefeld/Baden-Baden: Agis Verlag 1963. 
- The artificial (poiesis) informative processes are now based on digital technology.

This revitalization and replacement of the classic objective concept of information within a modern framework can be observed in Weizsäcker's thought for whom information is a double-bind category. It means (1) "what can be understood" as well as (2) "what generates information." ${ }^{17}$ Based on the Greek concepts of eidos/idea and morphé Weizsäcker makes a bridge not only with regard to the Greek and medieval concept(s) of information but also to the modern dichotomy between the objective and a subjective view. Weizsäcker shows that in Greek philosophy the concept of information, viewed from the perspective of its etymology as well as from its historic development is related to form or structure, i.e., to eidos/idea and morphé which mean not only objective forms but also to conceptual products of human knowledge expressed as linguistic entities with a univocal meaning. This is only possible within an open field of possible meanings, which is what language provides on the basis of context dependent notions. According to Weiszäcker there is consequently a productive or "hermeneutic circle" between language and information, language being a pre-condition of scientific thinking. Between the plurivocity and/or multivocity of natural language and the univocity of scientific concepts there is a recursivity which is typical of human thought as finite observers located within language and evolution (Weiszäcker, 1992).

Weizsäcker shows also that biological structures or even evolution itself can be conceived as a "growth of forms measured as growth of information." ${ }^{18}$ Forms can be

17 Carl Friedrich von Weizsäcker: Die Einheit der Natur, op.cit. p. 351-352: „1. Information ist nur, was verstanden wird. [...] 2. Information ist nur, was Information erzeugt." („1. Information is only what can be understood. [...] 2. Information is only what produces information.")

${ }^{18}$ Carl Friedrich von Weizsäcker: Information und Imagination. In Bayerische Akademie der Schönen Künste (Ed.): Information und Imagination. Munich: Piper 1973, p. 24: „so ist also Evolution ein Anwachsen der Menge an Form, gemessen als ein Anwachsen der Information." considered as potentially knowable which is what the second concept of information addresses. An organism can be understood as a product of genetic information. Weizsäcker calls these generative forms "objectified semantics" (Weizsäcker, 1974, p.351). In the field of thermodynamics actual information means the opposite to entropy while in the context of consciousness information has syntactic, semantic, and pragmatic dimensions. Weizsäcker translates the technical concept of information as signal transmission into the context of thermodynamics and biological evolution. Thermodynamic entropy measures the distance between knowledge at the macro and micro level. The probability of possible events takes place within specific conditions. This means also that there is no absolute concept of information. It also implies that forms or structures, either objective or subjective ones, are not seen as something permanent or absolute but as changing in time (lbid). Based on this duality of the concept of information, Holger Lyre develops a quantum theory of information with basic alternatives that represent the content of information as yes/no alternatives, i.e., as a quantum-theoretical bit of potential information called "Ur". ${ }^{19}$

This idea of units of information is prima facie similar to the theory of objective information developed by Tom Stonier (19271999) according to whom information, or more precisely "infons," exist independently of human knowledge, as intrinsic components of the universe (Stonier, 1997). This makes the difference to the Kantian approach of Weizsäcker and Lyre for whom the "Urs" are not spatial-temporal particles. Stonier distinguishes clearly between information and meaning. The underlying concept is message. According to Stonier information is, say, the letters of the alphabet or the nucleotides of a strand of DNA. The message or, better, the

19 Holger Lyre: Quantentheorie der Information. Vienna: Springer. According to Charles H. Bennett y David P. DiVicenzo: Quantum information and computation. Nature, 2000, 404, pp. 247-255, a theory of information based on quantum mechanics as well as on Shannon's theory offers benefits for cryptography as well for the quantum process of information. A quantum bit or "qubit" is a microscopic system similar to the atom. 
information transmitted by a message has a meaning only if it has been informationprocessed by a recipient (Stonier, 1996).

Since the beginning of 1990 the group Foundations of Information Science coordinated by Pedro Marijuán has discussed the concept of information following the paths opened by Stonier and other scientists. ${ }^{20}$ They have been searching for a unified theory of information that includes modern subjective as well as objective meanings underlying the pre-modern concept (Capurro, Fleissner \& Wolfgang, 1999). Some philosophers have questioned the use of the concept of information in natural sciences as a misleading analogy or as a redundant concept with regard to causality. ${ }^{21}$ Peter Fleissner and Wolfgang Hofkirchner have called this problem "Capurro's trilemma," being in fact an Aristotelian one. They point to the following options:

1. Univocity: the concept of information means the same in every context. Disadvantage: reductionism.

2. Analogy: the concept of information has an original meaning in a specific context, for instance in human communication and can be applied only analogically to other levels of reality. Disadvantage: anthropomorphism.

3. Equivocity: the concept of information has different meanings in different contexts. Disadvantage: Babel syndrome. Scientific discourses and theories remain encapsulated. (Fleissner \& Hofkirchner, 1995)

20 Pedro Marijuán (Ed.) First conference on foundations of information science. From computers and quantum physics to cells, nervous systems, and societies. Bio Systems 1996, 38, 87-96. See the site $<$ http://fis.icts.sbg.ac.at/>. See also Horst Völz: Information I - Studie zur Vielfalt und Einheit der Information; Information II - Ergänzungsband zur Vielfalt und Einheit der Information - Theorie und Anwendung vor allem in der Biologie, Medizin und Semiotik. Berlin: Akademie Verlag.

${ }^{21}$ Peter Janich: Informationsbegriff und methodischkulturalistische Philosophie. Ethik und Sozialwissenschaften, 1998, 2, pp. 169-182. See my criticisms in: "Das Capurrosche Trilemma" Ethik und Sozialwissenschaften, 1998, 2, pp. 188-189 and the discussion in my: Informationsbegriffe und ihre Bedeutungsnetze. Ethik und Sozialwissenschaften, 2001, 1, pp. 14-17.
This problem brings us to the debate on the concept of information in the humanities and social sciences (Qvortrup, 1993). It deals mainly with the reductionist syndrome, i.e., with the fear of reducing human beings to an information-processing machine giving up social and cultural dimensions. If, according to Gregory Bateson (1904-1980), "information is a difference that makes a difference" (Bateson, 1972, p.459) the question then arises as to what is the difference that makes of an observer a human one. One important aspect is selection. Information is the process as well as the product of selection. This aspect plays a key role in Shannon's theory of information which excludes, as we have seen, the semantic and pragmatic aspects of human selection as addressed in the modern notion of information. But although it is clear that human as well as non-human information processes deal with selection, they differ in the kind of interpretation as well as with regard to the relation between (deterministic) causality and (conscious) motivation. This is the reason why Yehoshua Bar-Hillel (19151975) pointed to the "ambiguities and semantic traps" in Shannon's theory of information that he prefers to call "theory of signal transmission." ${ }^{22}$ Bar-Hillel and Rudolf Carnap (1891-1970) developed a semantic theory of information where the concept of information is interpreted within a linguistic framework (Bar-Hillel \& Carnap, 1953). A similar but not identical theory was proposed by Fred Dretske based on the distinction between information and meaning. "Information is what is capable of yielding knowledge" and knowledge is relative to preknowledge (Dreske, 1981). The concept of information is thus intimately related to human knowledge or, more generally, to cognitive systems: "knowledge is information-produced belief" (Ibid, pp. 91-92). Cognitive systems capable of creating meaning are different from mere information processing ones such as computers that can only manipulate symbols.

22 Yehoshua Bar-Hillel: Language and information. London: Addison-Wesley 1973 (1a. ed. 1964), p. 296: "Even more important than the change of name from Information Theory to Theory of Signal Transmission (plus, perhaps, Theory of Coding) would be to discard the use of the term 'information' within this theory, with all its ambiguities and semantic traps." 
This cognitivist limitation was criticized by authors like Barwise, Perry, Israel and Seligman who developed a semantic theory based on the idea of regularity of different types of situations where Dretske's theory is seen as a particular case. Information does not refer to a property of something. It is context-dependent (Barwise \& Perry, 1983; Barwise \& Seligman, 1997; Israel \& Perry, 1990). Pérez-Montoro developed further this theory, disconnecting the concept of information from any kind of relation to a receiver's interpretation. The concept of information is fully situational and contingent, i.e., dependent on specific frameworks (Pérez-Montoro, 2007).

Based on systems theory, Oeser points to the objectivity of scientific knowledge that is not based on the elimination of the knower but on an intersubjective information process (Oeser, 1976). Information always has a system as framework of reference as conceived also by second-order cybernetics developed by biologists Humberto Maturana and Fracisco Varela (1946-2001) (Maturana \& Varela, 1980; Brier, 1999, Qvortrup, 1993). According to the computer scientist Heinz von Foerster (1911-2002), information is a mental difference within the observer who constructs or discovers a difference in the outside world (von Foerster, 1984). Sociologist Niklas Luhmann developed a theory of psychic and social systems where the construction of meaning is based on a communication process whose three elements are a meaning offer ("Mitteilung"), a selection ("Information"), and its integration ("Verstehen") within the system (Luhmann, 1987, pp. 193-194). This theory criticizes the metaphor of information as something that can be transmitted between a sender and a receiver. The sender makes already a selection as Shannon clearly saw. Other authors, such as Klaus Kornwachs, propose a pragmatic definition of information (Kornwachs, 1996).

Information is today a key concept in sociology, political science, and economics (Castells, 1995). According to Bougnoux, the concepts of information and communication are inversely related: communication refers to what can be foreseen as well as to redundancy, while information has to do with what is new and unforeseen. There is no "information in itself" as there is always some kind of redundancy or noise. To inform others or oneself means, according to Bougnoux, to select and to evaluate. This is particularly relevant in the field of journalism, mass media, and the Internet (Bougnoux, 1993). According to Alfons Cornella enterprises are information (Cornella, 2000). The concept of information plays a key role in theories of knowledge management. According to Nonaka and Takeuchi information is externalized and manageable and therefore it can only be potential knowledge because the latter is a process that takes place only within a cognitive subject. ${ }^{23}$ These theories are (implicitly) related to the long history of the concept of information in the library and information science field. ${ }^{24}$

To summarize, this discussion on the concept of information that takes place since the second half of the $20^{\text {th }}$ Century shows a growing interest on the objective meaning that was already part of the classic pre-modern tradition and which is interpreted now within the framework of empirical science and information technology. There is a tendency, questioned by some authors, to relativize or even eliminate the subjective dimension. It is obvious that at least five hundred years of using the notion of information in a subjective sense in everyday language cannot be ignored or easily forgotten even if the sciences define their concepts independently of the ordinary use, without always giving rise, as in this case, to a controversy that has not only a scientific but also a social and an ethical dimension. One main reason for this is that the objective concept of information has a backward effect on the self construction of the subject that sees him/herself as leveled by and deprived from specific differences with regard to non-human information-processing systems. But, in fact, the concept of information refers in many of its scientific meanings to "release mechanisms," as Karpatschof calls them (Karpatschof, 2000), which can be applied specifically in different

23 See for instance Ikujiro Nonaka and Hirotaka Takeuchi: The knowledge-creating company. New York: Oxford University Press, 1995.

${ }^{24}$ For a detailed analysis of the concept of information in the LIS field see Rafael Capurro and Birger Hjørland: The Concept of Information, op.cit., pp. 377-396. 
levels and contexts without reductionisms. In order for this to happen it is necessary to perform a genealogical study of this and other related notions and concepts that are crucial for our age. The tendency to see ourselves as objects is always latent and becomes virulent when objective knowledge and its technical instrumentalization become a global horizon since modernity.

\section{The future of the concept of information}

Within the framework of an emerging philosophy of information that until now does not seem to become aware of the complex past of this concept as well as of the underlying notion and its signifiers, Floridi defines information within the framework of Shannon's information theory (Floridi, 2004), as well as within the classical tradition of the concept of forma. Floridi's "informational objects" are similar to Leibniz' monads or Plato's ideas. They are seen also as messages with different kinds of "intrisic value" (Floridi, 2003; 1999; Capurro, 2003).

Following this path already opened by Weizsäcker, I would like to twist Floridi's ontological or I should better say metaphysical paradigm and reverse the foundational relation between message and form or "informational objects." ${ }^{25}$ । consider the givingness of such objects (or forms) - and the very fact of the given itself of such givingness - as the original informational or angeletic (from Greek ángelos = messenger) phenomenon that becomes manifest to a finite subject for whom his/her own being is (perceived as) given and to which he/she is capable to answer. The latter makes the heart of his/her existential responsibility towards what he/she can be. ${ }^{26}$ The concept of givenness, in contrast to the one of creation, is a phenomenological not a metaphysical one. We are responsible beings also in the

25 See my criticisms to Floridi's metaphysics of information in: Towards an ontological foundation of information ethics. Ethics and Information technology 8, 4, pp. 175-186.

26 See Heidegger's existential philosophy and his criticism of metaphysics in Martin Heidegger Sein und Zeit. Tübingen: Niemeyer 1976 and my: Towards an ontological foundation of information ethics, op.cit. sense of our capacity of selecting and answering messages or "meaning offers" (Luhmann, 1987). "What is received is received according to the receiver's form" (quidquid recipitur ad modum recipientis recipitur) as the medieval dictum says. ${ }^{27}$

The modern concept of information is grounded etymologically not only in the concepts of eidos/idea and morphe or forma but also, as far as it means "communicating something (new) to someone," in the concept of lógos and is related to the birth of philosophy. How far? As far as the Platonic Socrates replaces the heteronomic structure underlying the concepts of message and messenger through a method based on telling or giving each other reasons (logon didónal) instead of just letting oneself be told something by others, particularly if they occupy a place of power, i.e., having the capacity to command (Capurro, 1995). In other words, Socrates introduces nothing less than the principle of recursivity as a method for searching the truth. Socrates' polemics dealt with the concept of message (angelía) that was used particularly but not exclusively in political and/or military contexts but also in mythical and poetical ones. In this latter case it meant the activity of the poet as mediator or messenger between the gods and the human being, personified by Hermes, but also by Iris, the messenger(s) of the Olympic gods. ${ }^{28}$ Socrates propagates a message exchange that is seemingly horizontal while retaining the right to autonomy of the participants in such a dialogue. This allows the concept of message to enter into a dialectical inter-play with one important transformation with regard to the pre-socratic hierarchical scheme, namely the introduction of reversibility that allows the receiver of a message to transform herself into a sender.

Recursivity and reversibility are fundamental with regard to the present concept of information within the framework of cybernetics. It is not by chance that the concept of message as well as of medium is

27 See for instance Thomas Aquinas, Summa Theologica, I q.12 a.4 c.: "Cognitum autem est in cognoscente secundum modum cognoscentis."

${ }^{28}$ On the semantic context of angelía see my: Information, op.cit. pp. 46-49. 
at the core of Shannon's theory of communication and its aftermath. Who speaks about messages cannot avoid speaking about messengers. The difference between message and messenger is an important one. Plato's metaphysics imagines pure, metalinguistic or, so to speak, messenger-free messages or ideas located in a divine place (topos noetós) beyond the symbolic dimension of the world as perceived through language. A message without a messenger as well as a messenger without a message is a limiting concept. Not only information but also media theory can find a new basis in a theory of messages and messengers or angeletics (Capurro, 2003a; 1995; 2003b). This theory is still in its infancy although message societies develop themselves technologically and culturally with breathtaking speed. Information is a message that makes a difference, either as a form or as a "meaning offer." This postal paradigm interprets the classic Greek-Latin tradition of the concept of informatio from the modern communicational perspective. It goes beyond the rejection of the application of the concepts of information and message/messengers to non-human contexts when dealing with non-human communicational or postal processes. I suggest the need to explore and imagine models and rules that allow present and future societies to operate on the basis of a complex reversible exchange of messages and messengers, particularly digital ones. The limits of my history of the notion of information are obviously the ones of Western philosophical tradition as well as of some Western languages as far as the notion of information and message/messenger are concerned. The message of this paper, that has no missionary ambitions, is the idea of a paradigm that connects, without leveling differences, human and non-human angeletic phenomena. In a text that he considered his best book Ivan Illich writes:

"The book has now ceased to be the root-metaphor of the age; the screen has taken its place. The alphabetic text has become but one of many modes of encoding something, now called "the message»." (Illich, 1993, p. 3)
Maybe we are in the process of leaving the age of the book by going through the information age towards the age of messages and messengers. The information age has given us not only a new alphabet but also new forms of message codification using particularly digital messengers. We are not mere readers of the genetic code (Blumenberg, 1986). If we see it as a message we conceive ourselves, from the perspective of the "age of the book" (Illich, 1993), as writers. When texts, the ones of nature as well as the ones of culture, are conceived as messages, writers and readers become messengers. In order for this to work at the social level without vertical power structures that might stop arbitrarily such processes, it is necessary to develop bidirectional, horizontal, and recursive dispositifs of communication. ${ }^{29}$ The discussion on the concept of information in the $20^{\text {th }}$ Century has opened our eyes to the danger of a unilateral, vertical, and non-recursive transmission of messages. In other words, the modern concept of information works as a corrective with regard to the heteronomic concept of message. And vice versa, the concept of message shows something that underlies implicitly or explicitly the concept of information. The critical perception of this tension between autonomy and heteronomy, horizontality and verticality, information and message has been made possible today thanks to the system of interactive message transmission we call the Internet when we see it from the perspective of the genealogy of the concept of information that leads eventually to information ethics.

\section{Annex}

Real Academia Española: Diccionario de la Lengua castellana, llamado de Autoridades, Madrid 1734, tomo I, pp. 267-268:

"INFORMACION, s.f. El acto de informarse ò informar de algo. Lat. Informatio. Fuenm. S. Pio V.f.118. Por siniestras informaciónes desacreditados.

\footnotetext{
${ }^{29}$ With "dispositif", sometimes translated as "aparatus" or "device", we are recalling the term coined by Foucault (1977).
} 
Información. Se llaman en lo forense las diligencias jurídicas que se hacen de cualquier hecho ù delito, para averiguarle, $y$ certificarse de su verdad. Lat. Inquisitio. Cerv. Quix. Tom.I.cap.41. Hecha su información de quanto le convenia, se fué à la Ciudad de Granáda. Quev. Mus.7.Rom.Satyr. que empieza, Pues me haceis casamentero.

Al caminante en los Pueblos

Se le pide información,

Temiendole mas que à peste.

Información. Se llama en la Philosophía la introducción de la forma en la matéria, para formar el compuesto. Lat. Informatio.

Informaciónes. En plural, se llaman las diligencias secretas, que se hacen de la calidad y nobleza de alguno, en orden à conferirle algun oficio, dignidad ò insignia. Lat. Secretae inquisitiones. Establec. de Sant. Tit. 2. cap. 14. Mandámos, que despues de vistas en el Consejo las informaciónes, que se hacen para Hábitos de Caballeros, se tornen à cerrar y sellar.

Información en derecho. La alegación escrita, que el Abogado hace para instruir à los Jueces de la justicia de alguna de las partes, en los pleitos y causas civiles o crimináles. Cald. Aut. La immunidad del sagrado.

.... Yo he de llenarlàs,

Cumpliendo de esse volumen

Lo que à la esperanza falta,

Con la nueva información,

Que en derecho en favor haga.

INFORMANTE. S.m. El que lleva la comissión y el cargo de hacer las informaciónes de calidad y nobleza, ò limpieza. Lat. Inquisitor secretus. Recop. Lib. 1.tit.7,I.35. En tal caso se podrán examinar los testigos que en él se citan, como pudiera el informante examinarlos por sí mismo.

INFORMAR. V.a. Term. Philosóphico. Dar la forma à la materia, ò unirse con ella. Lat. Informare, que es de donde viene. Cald. Aut. A Dios por razon de estado.
En embrion el alma, aun no

Informa órganos al cuerpo.

Informar. Vale tambien dar noticias à alguno ò ponerle en el hecho de alguna cosa. Lat. Informare. Certiorem facere. Cerv. Quix. Tom1,cap.22. Pidió à los que iban en su guarda fuessen servidos de informarle, y decirle la cáusa, ò causas por que llevaban aquella gente. Saav. Empr. 66. La peregrinacion es gran Maestra de la prudencia, quando se emprende para informar, no para deleitar solamente el ánimo.

Informar. Significa tambien decir, ò poner en el hecho y derecho de alguna causa al Juez, el Abogado de ella para que sentencie. Lat. Certiorem facere. Informare. Cald. Aut. La immunidad del sagrado.

... No me acobarda

La competéncia; en derecho

sabré informar....

Informarse. Vale tambien tomar noticias ò inquirir alguna cosa. Lat. Inquirere. Grac. Xenoph.lib.4.f.37. Yo me informaré como y quando, $y$ en qué tiempo los hirieron, y daré mi parecer sobre ello. Mend. Vid. De N. Señora, Copl.112.

Infórmase, y no resiste

Al soberano decreto,

Que no en todas ocasiones

Quiere Dios sentidos ciegos.

INFORMADO, DA. part.pass. del verbo Informar en sus acepciones. Lat. Informatus. Inquisitus. Marian.Hist.Esp.lib.7.cap.2. Los Moros informados de lo que pretendía Don Pelayo, por la huella, fueron en su busca.

INFORME. s.m. El mismo hecho de informar, ù dar noticia de alguna cosa. Lat. informatio. Cruzad.Cort.Sant.tom.3. Pass.del odio, fest.4. Aunque no tengan mas fundamento, que un mal informe y una mentira.

Informe. En lo forense significa la oración que hace el Abogado, en hecho y derecho de la causa que defiende. Lat. Informatio." 


\section{References}

Austin, J.L. (1961). Philosophical Papers. J.C. Urmson \& G.J. Warnock (Eds.). Oxford: Clarendon Press.

Bar- Hillel, Y. (1973). Language and Information. London: Addison-Wesley ( $1^{\text {st }}$ Edition 1964)

Bar- Hillel, Y. \& Carnap, R. (1953).3). Semantic information. British Journal of Science. 4, 147-157.

Barwise, j. \& Perry, J. (1983). Situations and Attitudes. Cambridge: MIT Press.

Barwise. J. \& Seligman, J. (1997). Information Flows: The Logic of Distributed Systems, Cambridge, UK: Cambridge University Press.

Bateson, G. (1972). Steps to an Ecology of Mind. New York: Ballantine Books.

Bennett, C.H. \& DiVicenzo, D.P. (2000). Quantum information and computation. Nature, 404, 247-255.

Blumenberg, H. (1986). Die Lesbarkeit der Welt. Frankfurt am Main: Suhrkamp.

Bougnoux, d. (1993). Sciences de l'information et de la communication. Paris: Larousse.

Brier, S. (1999). What is a possible ontological and epistemological framework for a true universal "information science?" The suggestion of a cybersemiotics. In W. Hofkirchner, W. (Ed.), The Quest for a Unified Theory of Information. Amsterdam: Gordon and Breach, pp. 79-99.

Buckland, M.K. (1991). Information and Information systems. New York: Praeger.

Capurro, R. (1978). Information. Ein Beitrag zur etymologischen und ideengeschichtlichen Begründung des Informationsbegriffs. Munich: Saur.

- (1995). Leben im Informationszeitalter. Berlin: Akademie Verlag.

- (1996) "On the Genealogy of Information". In Klaus Kornwachs y Konstantin Jacoby (Eds.): Information. New questions to a multidisciplinary concept. Berlin: Akademie Verlag 1996, pp. 259-270. [Online version] <http://www.capurro.de/cottinf.htm>

- (2001). Informationsbegriffe und ihre Bedeutungsnetze. Ethik und Sozialwissenschaften, 1(12), 14-17. $<$ http://www.capurro.de/ropohl.htm>

- (2003a). Angeletics - A Message Theory. In: Hans H. Diebner, Lehan Ramsay (Eds.): Hierarchies of Communication. Karlsruhe: Verlag ZKM, pp. 58-71. <http://www.capurro.de/angeletics_zkm.html>

- (2003b). Ethik im Netz. Stuttgart: Franz Steiner Verlag.

- (2006). Towards an ontological foundation of information ethics. Ethics and Information Technology, 8(4), 175-186.

Capurro, R. \& Hjørland, B. (2003). The Concept of Information. In Blaise Cronin (Ed.): Annual Review of Information Science and Technology (ARIST), Medford, NJ: Information Today, 37 (2003), 343-411. [Draft version Online] <http://www.capurro.de/infoconcept.html> [consulted 02/04/2010]

Capurro, R.; Fleissner, P. \& Hofkirchner, P. (1999). Is a Unified Theory of Information Feasible? A Trialogue. In Wolfgang Hofkirchner (Ed.): The Quest for a Unified Theory of Information. Proceedings of the Second International Conference on the Foundations of Information Science. Amsterdam: Gordon and Breach, pp. 9-30. [Online version] $<$ http://www.capurro.de/trialog.htm>.

Castells, M. (1996-1998). The information age - Economy, society and culture. 3 Vol. Oxford, UK: Blackwell.

Cervantes, M. de (1991). Don Quijote de la Mancha. Barcelona: Editorial Planeta (Engl. transl. by J. Ormsby [Online] $<$ http://www.gutenberg.org/files/5921/5921.txt>)

Cornella, A. (2000): Infonomia.com. La empresa es información. Bilbao: Deusto.

Descartes, R. (1996). Meditationes de prima philosophia. Secundae Responsiones. In ibid.: Oeuvres, C. Adam \& P. Tannery (Eds.). Paris: Vrin, Vol. VII.

Dretske, F. I. (1981). Knowledge and the flow of information. Cambridge, MA: MIT Press.

Dretske, F. I. (1986). Minds, machines and meaning. In C. Mitcham, \& A. Huning (Eds.), Philosophy and technology II. Information technology and computers in theory and practice. Dordrecht, The Netherlands: Reidel, pp. 97-109.

Fleissner, P. \& Hofkirchner, W. (1995). Informatio revisited. Wider den dinglichen Informationsbegriff. Informatik-Forum 8 , 126-131.

Floridi, L. (1999). Information Ethics: On the Theoretical Foundations of Computer Ethics. Ethics and Information Technology, 1, 37-56. [Online] <http://www.wolfson.ox.ac.uk/ floridi/pdf/ieotfce.pdf>

- (2003). On the Intrinsic Value of Information Objects and the Infosphere. Ethics and Information Technology, 4, 287-

304. [Online] <http://www.wolfson.ox.ac.uk/ floridi/>

- (2004). Information. In ibid.: The Blackwell Guide to the Philosophy of Information. Oxford, UK: Blackwell, pp. 40-61.

- (Ed.) (2004). The Blackwell Guide to the Philosophy of Information. Oxford, UK: Blackwell.

Foerster, H. von (1984). Observing systems. Seaside, CA: Intersystems Publications.

Foucault, M. (1977). "Ornicar?". Bulletin périodique du champ freudien, 10 (1977), 62-93.

Furètière, A. (1725). Dictionnaire universel contenant tous les mots françois tant vieux que modernes, \& les termes de toutes les sciences et des arts. La Haya, Rotterdam: La Veuve van Dole ( $1^{\text {st }}$ Edition, 1690).

Günther, G. (1963). Das Bewußtsein der Maschinen: Eine Metaphysik der Kybernetik. Krefeld/Baden-Baden: Agis Verlag. 
Hartley, R.V.L. (1928). Transmission of Information. Bell System Technical Journal, 7, 335-363.

Heidegger, M. (1976). Sein und Zeit. Tübingen: Niemeyer 1976.

Hofkirchner, W. (ed.) (1999). The Quest for a Unified theory of information. Proceedings of the Second International Conference on the Foundations of Information Science. Amsterdam: Gordon and Breach.

Illich, I. (1993). In the vineyard of the text. A commentary to Hugh's Didascalion. The Chicago University Press.

Israel, D. \& Perry, J. (1990). What is information? In P. Hanson (Ed.), Information, language and cognition. Vancouver, BC: University of British Columbia Press, pp. 1-19.

Janich, P. (1998). Informationsbegriff und methodisch-kulturalistische Philosophie. Ethik und Sozialwissenschaften, 2, 169182.

Karpatschof, G. (2000). Human activity: Contributions to the anthropological sciences from the perspective of activity theory. Copenhagen: Dansk Psykologisk Forlag.

Kornwachs, K. (1996). Pragmatic information and system surface. In K. Kornwachs y K. Jacoby: Information. New questions to a multidisciplinary concept. Berlin: Akademie Verlag, pp. 163-185.

Lalande, A. (1991). Vocabulaire technique et critique de la philosophie. Paris: Presses Universitaires de France.

Luhmann, N. (1987). Soziale Systeme. Frankfurt am Main: Suhrkamp.

Lyre, H. (1998). Quantentheorie der Information. Vienna: Springer.

Machlup, F. (1983). Semantics quirks in studies of information. In: Fritz Machlup \& Una Mansfield (Eds.): The Study of Information. Interdisciplinary Messages. New York: Wiley, pp. 641-671

Machlup, F. \& Mansfield, U. (eds.) (1983). The Study of Information. Interdisciplinary Messages. New York: Wiley.

Margel, S. (1995). Le tombeau du dieu artisan. Paris: Éditions du Minuit.

Marijuan, P.C. (1996). First conference on foundations of information science. From computers and quantum physics to cells, nervous systems, and societies. Bio Systems 38, 87-96.

Maturana, H.R. \& Varela, F.J. (1980). Autopoiesis and cognition. Dordrecht, The Netherlands: Reidel.

Nonaka, I. \& Takeuchi, H. (1995). The knowledge-creating company. New York: Oxford University Presss

Oeser, E. (1976). Wissenschaft und Information. Vienna: Oldenbourg.

Pérez gutiérrez, M. (2000). El fenómeno de la información. Una aproximación conceptual al flujo informativo. Madrid: Trotta. (Engl. transl.: M. Pérez-Montoro [sic] (2007). The Phenomenon of Information. A Conceptual Approach to Information Flow. Lanham, Maryland: Scarecrow Press).

Peters, J.D. (1988). Information: Notes toward a critical history. Journal of Communication Inquiry, 12, 10-24.

Qvortrup, L. (1993). The controversy over the concept of information. An overview and a selected and annotated bibliography. Cybernetics \& Human Knowing 1(4), 3-24.

Ritter, J. et al. (ed.) (1971 ss.). Historisches Wörterbuch der Philosophie. Darmstadt: Wissenschaftliche Buchgesellschaft.

Schnelle, H. (1976). Information. In J. Ritter (Ed.), Historisches Wörterbuch der Philosophie, IV. Stuttgart: Schwabe, pp. 116-117.

Shannon, C. E. (1948). "A Mathematical Theory of Communication". Bell System Technical Journal, 27, 379-423, 623-656.

Shannon, C. E. \& Weaver, W. (1972). The mathematical theory of communication. Urbana, IL: University of Illinois Press (primera edición 1949).

Stonier, T. (1990). Information and the Internal Structure of the Universe: An Exploration into Information Physics. London: Springer.

Stonier, T. (1997). Information and meaning: An evolutionary perspective. London: Springer.

Stonier, T. (1996). Information as a basic property of the universe. Bio Systems 38, 135-140.

Tomas Aquinas. (1923). Summa Theologicae. Ed. Leonina, Roma: Forzanti.

Ursul, A.D. (1970). Information: Eine philosophische Studie. Berlin: Dietz.

Völz, H. (1982/1983). Information I - Studie zur Vielfalt und Einheit der Information; Information II - Ergänzungsband zur Vielfalt und Einheit der Information - Theorie und Anwendung vor allem in der Biologie, Medizin und Semiotik. Berlin: Akademie Verlag.

Webster, F. (1995). Theories of the information society. London: Routledge.

Weizsäcker, C. F. von. (1973) Information und Imagination. In: Bayerische Akademie der Schönen Künste (Ed.): Information und Imagination. Munich: Piper.

- (1974). Die Einheit der Natur. Munich: DTV.

- (1985). Aufbau der Physik. Munich: Hanser.

- (1992). Zeit und Wissen. Munich: Hanser.

Wiener, N. (1961). Cybernetics or control and communication in the animal and the machine. New York: MIT Press 2nd ed. ( $1^{\text {st }}$ ed. 1948).

Wittgenstein, L. (1984). Philosophische Untersuchungen. Frankfurt am Main: Suhrkamp . 


\section{About the Author}

\section{Rafael Capurro}

Born 1945 in Montevideo, Uruguay (Ph.D. in Philosophy at Düsseldorf University, 1978, Thesis: Information) is currently director of the Steinbeis Transfer Institute - Information Ethics (STI-IE, Steinbeis University Berlin) as well as founder and director of the International Center for Information Ethics (ICIE); member of the European Group on Ethics in Science and New Technologies (EGE) to the European Commission (since 2001); member of the International Society for Ethics and Information Technology (INSEIT); Founding Member of The World Technology Network (WTN); Member of The Nanoethics Advisory Board (since 2006); Senior Fellow in Information Ethics, since 2007, at the Center for Information Policy Research, School of Information Studies, University of Wisconsin-Milwaukee, USA. He was Professor of information management and information ethics at the Stuttgart Media University (until 2008) and lecturer at the Stuttgart University.

Capurro Is Chief Editor of the International Review of Information Ethics (IRIE) and co-editor or adviser of other 5 international journals in the field. He has authored hundreds of articles, reviews, book chapters and books, and edited many others. 